\title{
Exsolution lamellae in a clinopyroxene megacryst aggregate from Cenozoic basalt, Leizhou Peninsula, South China: petrography and chemical evolution
}

\author{
Xiao-Long Huang $\cdot$ Yi-Gang Xu $\cdot$ Ching-Hua Lo \\ Ru-Cheng Wang · Chuan-Yong Lin
}

Received: 1 August 2006/Accepted: 27 April 2007/Published online: 26 May 2007

(C) Springer-Verlag 2007

\begin{abstract}
Petrographic investigations and electron microprobe analyses have been performed on a rare aggregate of clinopyroxene megacrysts collected from Cenozoic basalts in Yinfengling, Leizhou Peninsula of South China. The aggregate, composed of several clinopyroxene megacrysts, shows abundant exsolution lamellae of garnet (Grt) and orthopyroxene (Opx), and granular texture. $\mathrm{Cr}-$ and Ti-poor spinels are also present in this sample. They occur predominantly as $\mathrm{Sp}-\mathrm{Opx}-\mathrm{Grt}$ clusters $(\mathrm{Cr} \#=$ $0.025-0.034)$ at the interspace between different megacrysts, and subordinately as bleb-shaped $(\mathrm{Cr} \#=0.025-$ $0.034)$ or thin-lamella crystals $(\mathrm{Cr} \#=0.006-0.021)$ in
\end{abstract}

Communicated by J. Hoefs.

Electronic supplementary material The online version of this article (doi:10.1007/s00410-007-0218-4) contains supplementary material, which is available to authorized users.

X.-L. Huang · Y.-G. Xu ( $\square)$

Key Laboratory of Isotope Geochronology and Geochemistry, Guangzhou Institute of Geochemistry,

Chinese Academy of Sciences, Guangzhou 510640,

People's Republic of China

e-mail: yigangxu@gig.ac.cn

C.-H. Lo

Department of Geosciences, National Taiwan University,

Taipei 106, Taiwan

R.-C. Wang

State Key Laboratory for Mineral Deposits Research,

Department of Earth Sciences, Nanjing University,

Nanjing 210093, People's Republic of China

C.-Y. Lin

Institute of Geology, China Seismological Bureau,

Beijing 100029, People's Republic of China clinopyroxene. Three different assemblages of exsolution are identified, namely (1) Sp (high $\mathrm{Cr} / \mathrm{Al}$ ) and $\mathrm{Opx}$; (2) Grt-Opx; (3) Sp (low Cr/Al) and Opx. In addition, some garnets were likely developed as response to breakdown of the high-Cr/Al Sp. The homogeneous compositions in all constituent minerals and the good agreement between calculated $\mathrm{Cpx} / \mathrm{Grt}$ partition coefficients $\left(K_{\mathrm{d}}\right.$ 's) for trace elements and reference data strongly suggest a chemical equilibrium among coexisting minerals, probably attained by diffusion after the exsolution. Thermobarometric calculation based on exsolved assemblage yields a temperature of $900 \pm 30^{\circ} \mathrm{C}$ and a pressure of $12 \pm 2.2 \mathrm{kbar}$, corresponding to the present-day thermal gradient in the region. Much higher $\mathrm{P}-\mathrm{T}$ estimates $\left(T=1,210 \pm 30^{\circ} \mathrm{C}\right.$, $P=16.2 \pm 3.5 \mathrm{kbar}$ ) are obtained for the reconstructed composition of cpx prior to exsolution. The contrast in thermal state before and after the exsolution might reflect the thermal evolution of the lithosphere beneath South China during the Cenozoic.

\section{Introduction}

Exsolution of garnet in pyroxene has been widely reported in pyroxene megacrysts and eclogite xenoliths within kimberlites (e.g., Green 1966; Lappin and Dawson 1975; Aoki et al. 1980; Clarke and Pe-Piper 1982; Sautter and Hart 1988, 1990; Jerde et al. 1993; Schmickler et al. 2004) and in eclogite in metamorphic complexes (e.g., Reiche and Bautsch 1985; Zhang and Liou 2003). Such exsolution phenomena are generally related to a change in the thermal condition of the upper mantle where the sample resides (e.g., Aoki et al. 1980; Sautter and Hart 1988, 1990; Jerde et al. 1993; Zhang and Liou 2003) and thus can be used to 
reconstruct the thermal history of the lithosphere in a given region. Comparatively, similar exsolutions are apparently rare in pyroxene megacrysts in alkali basalt. Whether this is related to different thermal conditions for kimberlite and basalt generation or to different composition of host magmas is an open question.

In this contribution, we report a rare aggregate (GYX29) of clinopyroxene megacrysts collected from a Cenozoic basaltic breccia at Yingfengling in the Leizhou Peninsula, South China (Fig. 1). This sample shows typical exsolution of garnet and orthopyroxene in clinopyroxenes, and a variety of textures and subsolidus spinel-garnet reactional features, thereby providing a good opportunity to study the exsolution process in clinopyroxene and spinelgarnet facies transition in an Fe-rich system. In addition, previous studies on the peridotite xenoliths from Hainan and Qilin suggest a polybaric melting process beneath the mantle in South China, which was probably associated with upwelling of a hot asthenosphere and subsequent cooling (Xu et al. 2002). These arguments are largely based on geochemical modeling and await confirmation from other sources.

The objectives of this paper are:

(1) to describe the petrographic features of the exsolution phenomena and reaction assemblage associated with the spinel-garnet phase transition;

(2) to provide chemical analyses on host and exsolved phases of the megacryst and to assess the chemical equilibrium between them;
(3) to investigate the thermal variation associated with exsolution processes and phase transitions and to provide constraints on regional thermal evolution.

\section{Geological background}

The Leizhou Peninsula, together with the northern part of the Hainan Island, is the largest province of exposed late Cenozoic basalts in southern China (Fig. 1) (Ho et al. 2000; Yu et al. 2003). The volcanism began in the late Oligocene, gradually increased during the Miocene and Pliocene epochs and lasted in Holocene. Volcanism was controlled by the east-west extensional tectonic environment that led to the formation of the South China Sea Basin (Ho et al. 2000). The early volcanism was dominated by flood-type fissure eruptions of quartz tholeiites and olivine tholeiites, whereas the later phase was dominated by eruptions from central volcanoes producing alkali olivine basalts and basanite, which contain abundant ultramafic xenoliths, minor granulite xenoliths and megacrysts (Fan and Menzies 1992; Ho et al. 2000; Yu et al. 2003). The Yinfengling volcanic breccia, located at the center of the Leizhou Peninsula (Fig. 1), consists of four layers of different basaltic volcanic rocks interbedded with laterite; from bottom to top these are massive basaltic lava, fine pyroclastic rocks, basaltic tuff and breccia and basaltic agglomerate ( $\mathrm{Yu}$ et al. 2003). The ${ }^{40} \mathrm{Ar} /{ }^{39} \mathrm{Ar}$ ages of the three layers of volcanic rocks from bottom to top are 1.37,
Fig. 1 A sketch map showing the tectonic framework in South China and location of sampling area (the star) (modified from $\mathrm{Xu}$ et al. 2002)

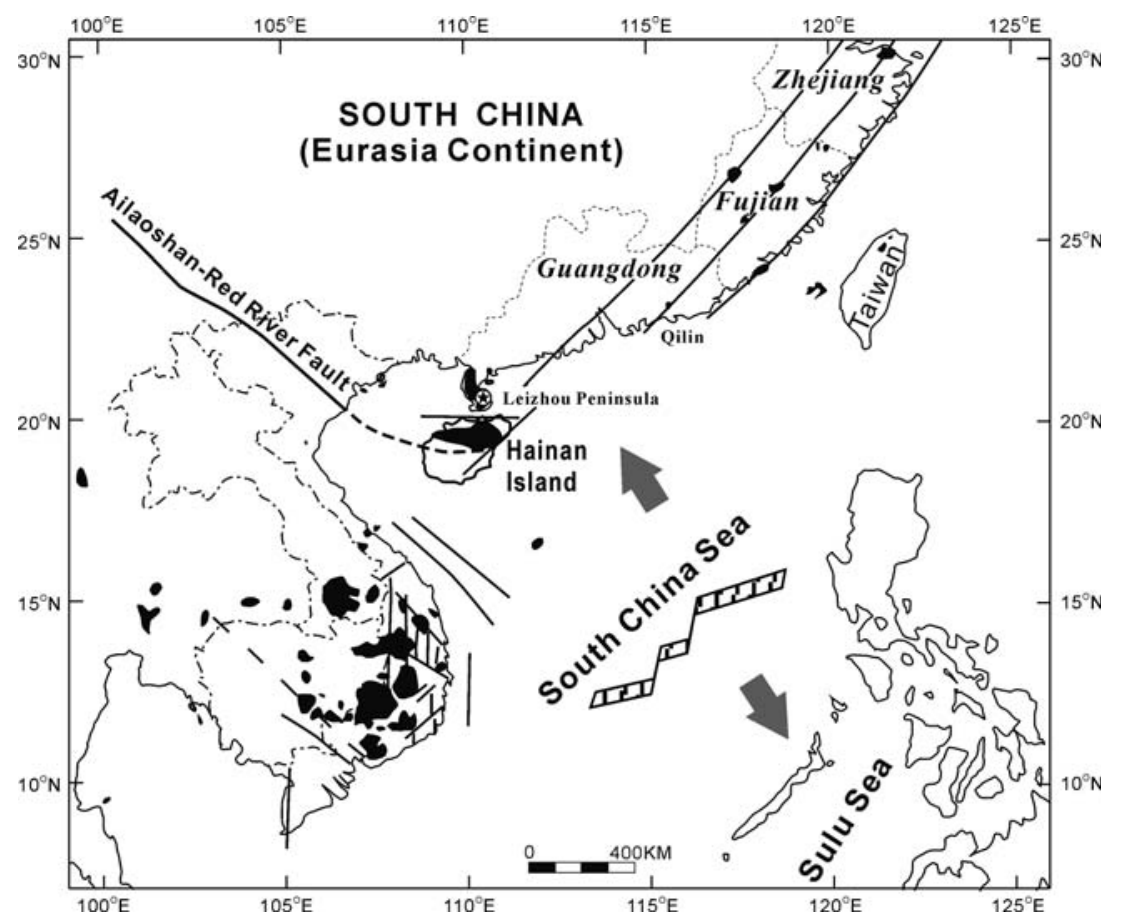


0.41-0.39 and 0.34 Ma, respectively (Xu et al. 1999). Abundant peridotite and pyroxenite xenoliths and megacrysts are found mainly in the third and the fourth layers of pyroclastic rocks (Yu et al. 2003).

\section{Analytical techniques}

Compositions of silicates (Etable 1) were obtained at Nanjing University with a JEOL JXA-8800M Superprobe. All traverse analyses and back-scattered-electron imaging were carried out at the Guangzhou Institute of Geochemistry, Chinese Academy of Sciences (GIG-CAS) with a JEOL JXA-8100 Superprobe. The operating conditions are as follows: $15 \mathrm{kV}$ accelerating voltage, $20 \mathrm{nA}$ beam current, $1-2 \mu \mathrm{m}$ beam diameter, $10 \mathrm{~s}$ counting time and ZAF correction procedure for data reduction. For the same mineral, the analytical results from two laboratories were compatible, which could be deduced from the small standard deviations listed in Etable 2.

Two thin sections were cut along different orientations. The modes of host clinopyroxene and exsolved garnet and orthopyroxene in three parts (Regions $G-a, L-a$, and $L-b$ ) of these two thin sections were estimated by using an imageprocessing software. We first took the digital photos of the two thin sections and then identified the constituent minerals (garnet, clinopyroxene, orthopyroxene and spinel) under microscope and mapped on the sketch diagram (Fig. 2). The image-processing software (Adobe Photoshop 6.0) was used to calculate the pixel proportions of minerals in terms of distinct colors of each mineral in Fig. 2. The error was lower than $5 \%$.

In situ trace element analyses of garnet and clinopyroxene were performed by laser-ablation-inductively coupled plasma mass spectrometry (LA-ICP-MS, Agilent 7500a) at the State Key Laboratory of Geological Processes and
Mineral Resources, China University of Geosciences. The laser-ablation system is a GeoLas 2005 (MicroLas, Gottingen, Germany), which is equipped with a $193 \mathrm{~nm}$ ArF-excimer laser and a homogenizing, imaging optical system. The conditions of $60 \mu \mathrm{m}$ spot size and $80 \mathrm{~Hz}$ energy density were adopted. External calibration was performed using NIST 610. Ca was used for internal standardization. Analyses of the USGS standards (BHVO-2g and BCR-2g) indicated precision and accuracy both better than $4 \%$. For clinopyroxene, the relative standard deviations (RSD) of Ba, HREE, $\mathrm{Hf}, \mathrm{Nb}, \mathrm{Ta}, \mathrm{Pb}, \mathrm{Th}$ and $\mathrm{U}$ were reduced to $5-10 \%$. For garnet, RSDs of $\mathrm{Ce}, \mathrm{Pr}, \mathrm{Nd}$ and $\mathrm{Sr}$ varied in the range of 5-20\%, while those of $\mathrm{La}, \mathrm{Nb}, \mathrm{Ta}, \mathrm{Pb}$, Th and $\mathrm{U}$ were high at $20-40 \%$ because of very low concentrations of garnet.

\section{Petrographic observation}

The studied sample GYX-29 is an aggregate $(4 \times 4 \times$ $6.5 \mathrm{~cm}^{3}$ ) consisting of several clinopyroxene megacrysts and some spinels (Fig. 2). Clinopyroxene megacrysts contain exsolved garnets and orthopyroxenes (Figs. 2, 3). Garnets commonly show retrograde alteration in the rim area (Fig. 3), probably due to rapid transport by host basalts to the surface. Most of the exsolved garnets in GYX-29 are red dust in plain polarized light and display heteromorphism in cross-polarized light. Fresh garnet is observed in the core of some thick lamellae or coarse-grained crystals. The aggregate displays two distinct textural zones (Figs. 2, 3), namely a lamellar zone and a granular zone. Spinel is present in both the lamellar and granular zones.

\section{Lamellae zone}

Parallel lamellae of garnet and orthopyroxene are present throughout the host clinopyroxene (Fig. 2). As a whole,
Fig. 2 Line-drawing of two thin sections of GYX-29 cut along different orientations. Ga, L-a, L-b, and L-s are regions of granular part-a, lamellae part$a$, lamellae part-b, and thin lamellae spinel part, respectively. The squares of $4 \mathrm{a}-$ $\mathrm{d}$ are enlarged in Fig. 4a-d

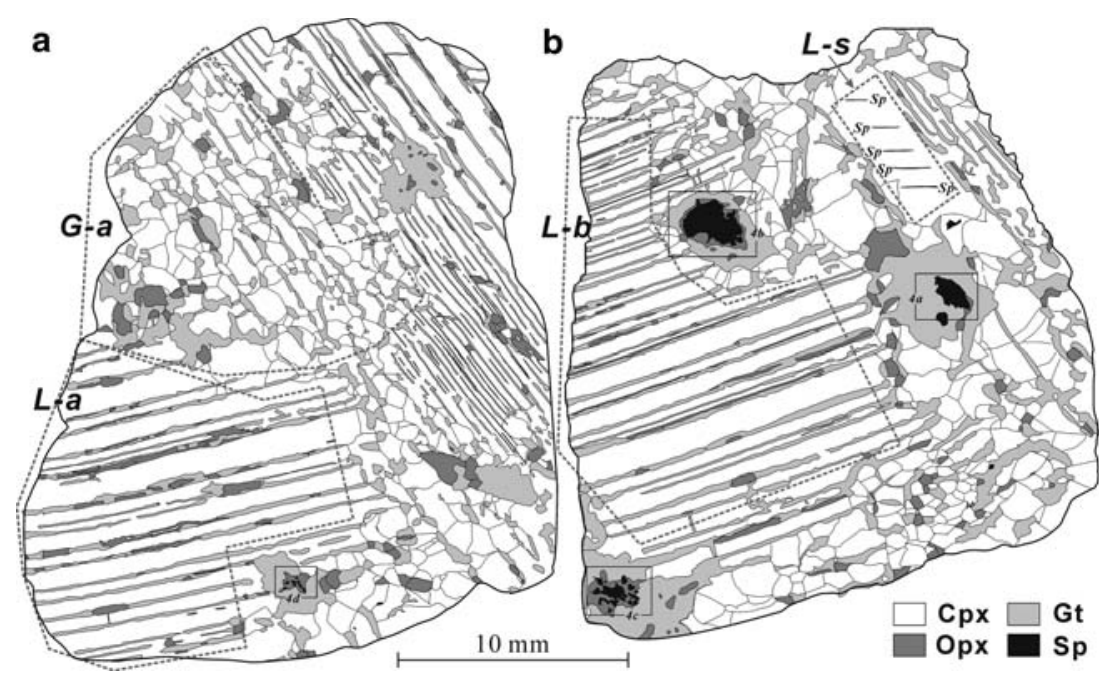


Fig. 3 Back-scattered-electron images of GYX-29: a lamellae exsolution of Grt and Opx in Cpx; b garnet lamellae showing retrograde feature along the rim area; c, d Opx, Grt, and Cpx developed a granular texture, and the bleb-shaped spinel at the junction of granular Cpx, Opx, and Grt. Line A-B marks the traverse analyses by electron microprobe

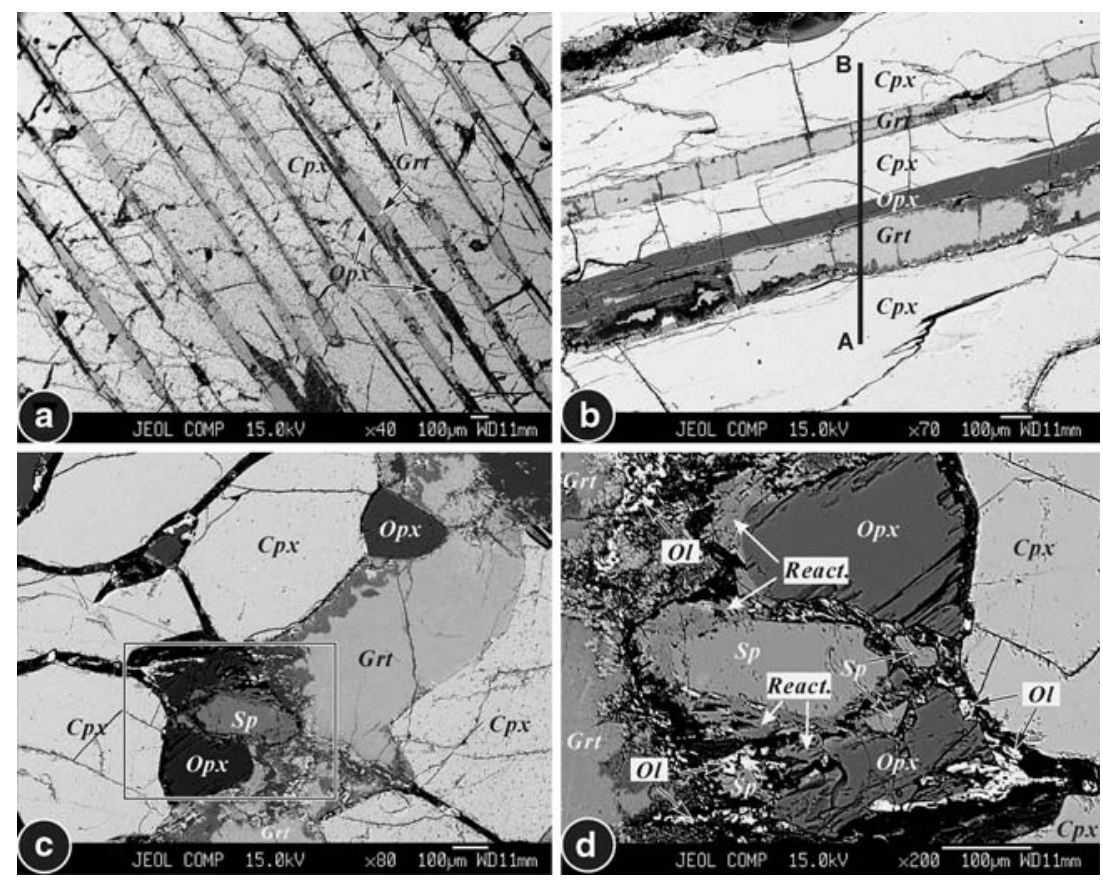

garnet lamellae are more common than Opx lamellae. The single lamellae are sometimes entirely composed of garnet or orthopyroxene (Figs. 2, 3a, b), but most often contain both minerals. The occurrence of two minerals in single lamellae is complicated. For instance, in some cases, garnet is cut by orthopyroxene, but in other cases Opx is enclosed by garnet or vice versa. Sometimes, the two minerals run parallel (Figs. 2, 3a). The complex spatial relationship between Grt and Opx makes it difficult to define the exsolution order of these minerals. Most likely, they were exsolved simultaneously.

The wavelength of the lamellae is variable from crystal to crystal and even within a single crystal, but the spacing between thick lamellae is always larger than that between thin lamellae (Fig. 2). Lamellar orientations are always controlled by the crystallographic structure of the host clinopyroxene. The growth of lamellae in sub-Fe Cpx is along planes close to (100) and (001), which is due to minimization of strain energy between the host and lamellae (Weinbruch et al. 2003). The orthopyroxene lamellae are always formed along (100) with the host clinopyroxene than exsolved garnet (Desnoyers 1975; Sautter and Hart 1988; Weinbruch et al. 2003). The lamellae of garnet-orthopyroxene in GYX-29 are also along the plane (100) of the host clinopyroxene, because they are almost parallel to the cleavage in the sections of lamellae part-a and part-b (Fig. 2).

\section{Granular zone}

Along the interspace between different clinopyroxene megacrysts, orthopyroxene, garnet, and clinopyroxene be- come significantly coarser, resulting in a granular texture (Figs. 2, 3c), which is similar to that observed in other mantle xenoliths (Mercier and Nicolas 1975). Among the minerals in the granular zone, $\mathrm{Cpx}$ is the largest in grain size. Garnet is generally of elongated shape and runs parallel to the exsolved lamellae in the host megacrysts.

\section{Spinels}

Three different types of spinels are distinguished. Coarse spinels up to $5 \mathrm{~mm}$ usually occur in the transitional zone between the lamellar and granular parts. They show irregular shapes (Fig. 4a-d) and disaggregated aureoles (Fig. 4c). In most cases, these spinels are enveloped by orthopyroxenes (Figs. 2, 4b-d), which are further enclosed by garnet, forming spinel-orthopyroxene-garnet clusters (Fig. 2). In a rare case, spinel is directly enclosed by garnet with only minor Opx occurring between the garnet and spinel (Fig. 4a). It is noted that garnet enclosing spinel is somehow connected to the exsolution lamellae (Fig. 2).

The second type of spinel is closely associated with garnet-orthopyroxene lamellae in clinopyroxene. Commonly of bleb shape, it appears in association with garnet (Fig. $4 \mathrm{e}-\mathrm{g}$ ). These spinels have an irregular reaction rim, composed of Opx and olivine (Figs. 3c, d, 4e-g). Anhedral olivines are distributed nearby as irregular crystals at the interface between granular Opx, Cpx, and Grt (Fig. 3c, d).

The third type of spinels occur as isolated and parallel lamellae in the interior of clinopyroxene (Figs. 2b, $4 \mathrm{f}-\mathrm{h}$ ). A small amount of fine-strip spinels in host clinopyroxenes are parallel to exsolution lamellae of garnet-orthopyroxene (Fig. 4f). The fine-strip spinels all cut thin 
Fig. 4 a-d Showing the different stages of development of Sp-Opx-Grt clusters: a spinel enclosed by garnet with local appearance of Opx between them; b Opx was developed to completely enclose spinel; garnet showing reaction rims; c spinel is disintegrated to small aggregates in growing orthopyroxene; $\mathbf{d}$ further resorption of spinel; e-g blebshaped spinel included in exsolution lamellae of Grt-Opx and irregular reaction rim and olivine; $\mathbf{f}$ fine strip spinel is parallel to exsolution lamellae of Grt-Opx in Cpx; $\mathbf{h}$ fine-strip spinel coexisting with orthopyroxene included in Cpx. Line C-D-E marks the traverse analyses by electron microprobe
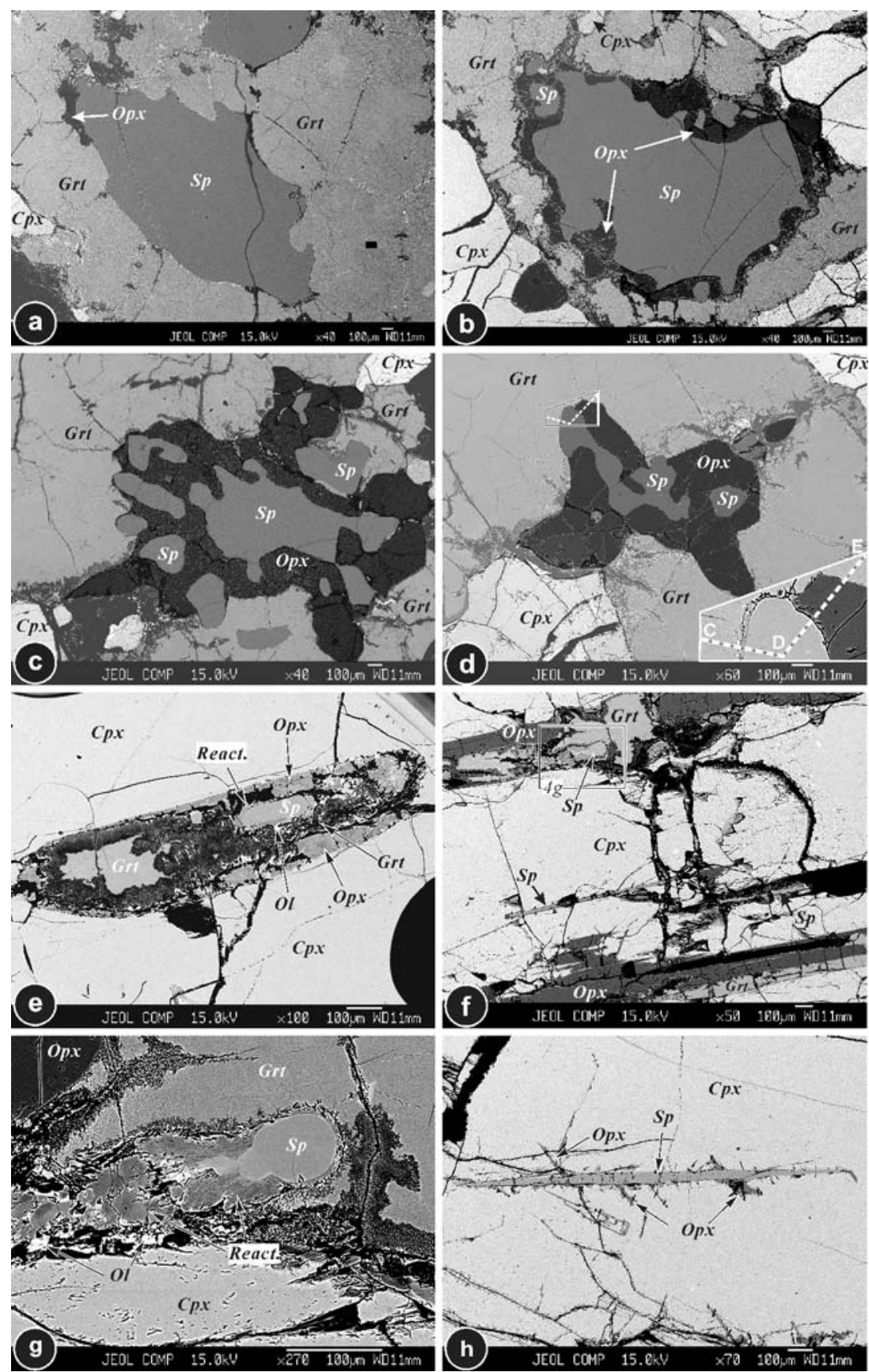

lamellae of orthopyroxene (Fig. 4h). This type of spinel shows no direct contact with garnet lamellae (Region L-s in Figs. 2b, 4h).

\section{Results}

Mineral chemistry

In order to evaluate the intracrystal and intercrystal chemical homogeneity, EMP analyses were carried out for both core and rim areas of the minerals. The results show no compositional difference in the minerals from the lamellar and granular zones (Etable 1; Figs. 5, 6, 7). No compositional gradients were observed among the host $\mathrm{Cpx}$ and exsolved Grt and Opx (Figs. 3b, 5a). This contrasts with the diffusive gradients of compositions for $\mathrm{Si}, \mathrm{Al}, \mathrm{Mg}$, $\mathrm{Fe}, \mathrm{Ca}$, and $\mathrm{Na}$ at the region near the exsolution lamellaes in unequilibrated samples (Sautter and Hart 1990; Jerde et al. 1993; Becker 1997; Xu et al. 2004). Therefore, it can be concluded that the sample GYX-29 attained chemical equilibrium after exsolution. 
Fig. 5 a Traverse analyses of lamellae exsolution of Grt and Opx in Cpx (line A-B shown in Fig. 3b). b Traverse analyses of Sp-Opx-Grt cluster (line C-D-E shown in Fig. 4d)

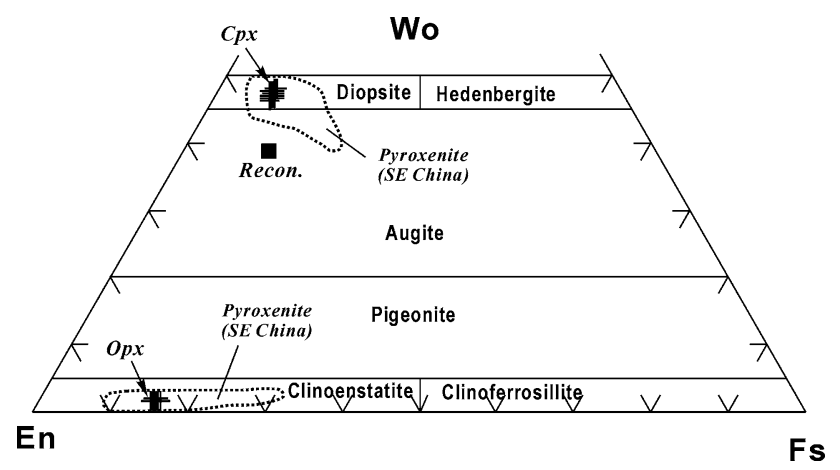

Fig. 6 Compositional characteristics of host clinopyroxenes, exsolved orthopyroxenes and reconstruction clinopyroxene of GYX-29. Data of pyroxenite xenoliths from Leizhou Peninsula and Qilin are from Yu et al. (2003), Lin et al. (2003), and Xu et al. (1996)

\section{Clinopyroxene and orthopyroxene}

The host clinopyroxenes $\left(\mathrm{En}_{44-46} \mathrm{Fs}_{7-8} \mathrm{Wo}_{46-48}\right)$ in GYX-29 are Na-bearing (1.1-1.4 wt. $\% \mathrm{Na}_{2} \mathrm{O}$ ) diopsides with jadeite (Jd) contents of 4-8\%. In most cases, Cpx are compositionally homogeneous. The only exception is the clinopyroxene in the region L-s (Fig. 2b) where parallel spinel lamellae occur. This $\mathrm{Cpx}$ is characterized by slightly lower $\mathrm{Al}_{2} \mathrm{O}_{3}$ (6.28 wt.\% in average) and higher $\mathrm{SiO}_{2}$ (51.2 wt.\% in average) (Etable 2) compared to the majority of analyses of the host Cpx (Etable 1).
The exsolved orthopyroxenes $\left(\mathrm{En}_{83-84} \mathrm{Fs}_{15-16} \mathrm{Wo}_{1-2}\right)$ are enstatite. Similar composition is found in Opx grains in the granular zone and Opx enveloping spinel in the Sp-OpxGrt clusters. The traverse analyses (Line C-D-E in Fig. 4d) reveals that minerals in the Sp-Opx-Grt clusters are compositionally homogeneous from the core toward the rim (Fig. 5b), and the undulation of garnet adjacent to spinel is most probably due to cracks in the rim area (Fig. 5b).

Both clinopyroxenes and orthopyroxenes in GYX-29 are compositionally similar to others in the pyroxenite xenoliths from the Cenozoic basalts of SE China (Fig. 6) (Xu et al. 1996; Yu et al. 2003; Lin et al. 2003).

\section{Garnet}

The cores of garnet show a homogeneous composition (Fig. 5a). However, $\mathrm{FeO}$ and $\mathrm{MgO}$ contents become elevated and $\mathrm{Al}_{2} \mathrm{O}_{3}, \mathrm{CaO}$ and $\mathrm{SiO}_{2}$ contents are lower toward the rims. This compositional variation may be due to retrograde alteration. The unaltered core of garnets in GYX29 has high $\mathrm{MgO}$ and $\mathrm{Al}_{2} \mathrm{O}_{3}$ content, but low $\mathrm{CaO}, \mathrm{TiO}_{2}$ and $\mathrm{Cr}_{2} \mathrm{O}_{3}$ content (Etable 1). The end-member compositions are dominated by pyrope (61-69\%), and contain subordinate almandine (16-23\%), grossulars (12-15\%) and andradites $(\sim 2 \%)$. They are distinctively different from the high contents of grossular and almandine in exsolved 


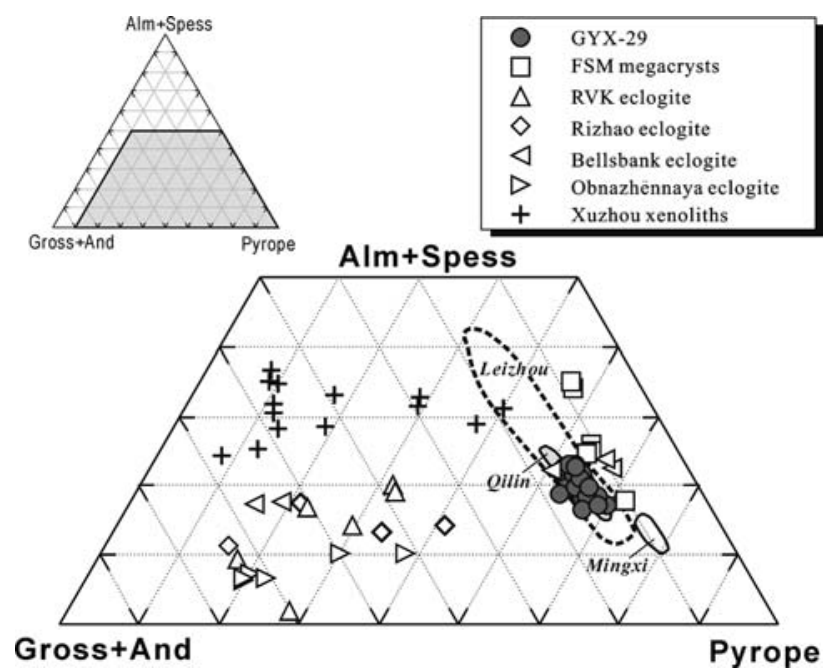

Fig. 7 (Alm + Spess)-(Gross + And)-Pyrope diagram for garnet. Abbreviations and source of data: FSM Megacrysts from the Frank Smith kimberlite (Clarke and Pe-Piper 1982), RVK, eclogite xenolith from the Roberts Victor kimberlite pipe (Sautter and Hart 1988), Rizhao eclogite from Sulu ultrahigh-pressure terrane of eastern China (Zhang and Liou 2003); Bellsbank ecologite of South Africa and Obnazhënnaya ecologite of Yakutia, Russia (Jerde et al. 1993); Xuzhou xenoliths from high-pressure terrane of eastern China (Xu et al. 2004); Leizhou pyroxenite xenolith (Yu et al. 2003); Qilin pyroxenite xenolith (Xu et al. 1996); Mingxi garnet peridotite xenolith (Qi et al. 1995)

garnets in Al-rich pyroxenes of eclogites (Fig. 7; Sautter and Hart 1988, 1990; Jerde et al. 1993; Zhang and Liou 2003). Garnets in GYX-29 are also slightly different from those in peridotite xenoliths of Mingxi, southeastern China (Qi et al. 1995), which contain higher pyrope contents (Fig. 7). However, they show compositional similarities to the exsolved garnets in the clinopyroxene megacrysts from the Frank Smith mine of South Africa (Aoki et al. 1980), and to those in the pyroxenite xenoliths from the Cenozoic basalts of Leizhou Peninsula and Qilin, SE China (Xu et al. 1996; Yu et al. 2003) (Fig. 7).

\section{Spinel}

All three types of spinels (i.e., fine strip, bleb-shaped, and cluster) are characterized by very low $\mathrm{Cr}_{2} \mathrm{O}_{3}, \mathrm{TiO}_{2}$ $(<0.2$ wt.\%), $\mathrm{NiO}(<0.4$ wt.\%) and $\mathrm{MnO}(<0.1$ wt. $\%)$ (Etable 2). They are compositionally different from those in peridotites xenoliths entrained by Cenozoic basalts of SE China (Xu et al. 1996, 2002; Yu et al. 2003) (Fig. 8a). Coarse spinels and spinel associated with garnet-Opx lamellae are similar in composition, with $\mathrm{Al}_{2} \mathrm{O}_{3}$ content ranging from 61.3 to 62.8 wt. $\%$ and $\mathrm{Cr}_{2} \mathrm{O}_{3}$ content from 2.34 to $3.21 \mathrm{wt} . \%(\mathrm{Cr} \#=0.025-0.034)$. The fine-strip spinels show slightly lower $\mathrm{Cr}_{2} \mathrm{O}_{3}(1.32-1.95$ wt.\%) and higher $\mathrm{Al}_{2} \mathrm{O}_{3}(62.7-64.3$ wt.\%) contents $(\mathrm{Cr} \#=0.006$ 0.021) (Fig. 8b; Etable 2).

The reaction rims of bleb-shaped spinels have high $\mathrm{Al}_{2} \mathrm{O}_{3}$ and $\mathrm{CaO}$ (Etable 2) and exhibit great variations in $\mathrm{SiO}_{2}, \mathrm{Al}_{2} \mathrm{O}_{3}, \mathrm{MgO}$ and $\mathrm{CaO}$.

\section{Trace elements compositions}

In situ trace element analyses have been carried out for both core and rim areas of the minerals in the lamellar and granular zones. Clinopyroxenes are homogeneous in terms of elemental concentrations (Table 1, Fig. 9a, b). Likewise, garnets are compositionally homogeneous with no difference in REE concentration between core and rim analyses (Fig. 9a, b). Relatively large variation in composition is noted for the elements ( $\mathrm{Th}, \mathrm{U}, \mathrm{Nb}, \mathrm{Ta}$, and $\mathrm{La}$ ) whose concentrations in garnet are close to the detection limit (Table 1). Clinopyroxene and garnet of GYX-29 display essentially reverse distribution patterns of REE and most trace elements (Fig. 9a, b; Table 1). Specifically, garnet

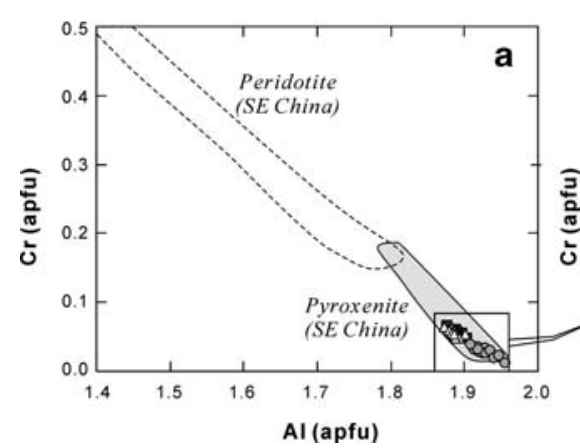

Fig. 8 a $\mathrm{Cr}-\mathrm{Al}$ plot showing that the composition of spinel in GYX29 resembles that of pyroxenite xenoliths, but differs from the peridotite xenoliths in the Cenozoic basalts of SE China (Xu et al. 1996, 2002; Yu et al. 2003). b Plot showing that fine-strip spinels

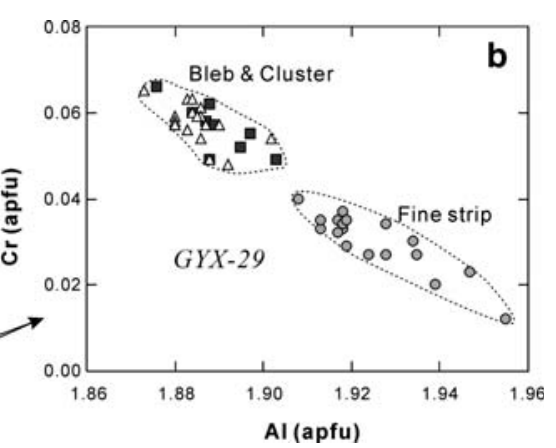

contain lower $\mathrm{Cr}$ and higher $\mathrm{Al}$ contents than the bleb-shaped spinels and the spinels in the spinel-orthopyroxene-garnet cluster. Apfu atoms per formula unit, calculated on the basis of four atoms of oxygen 


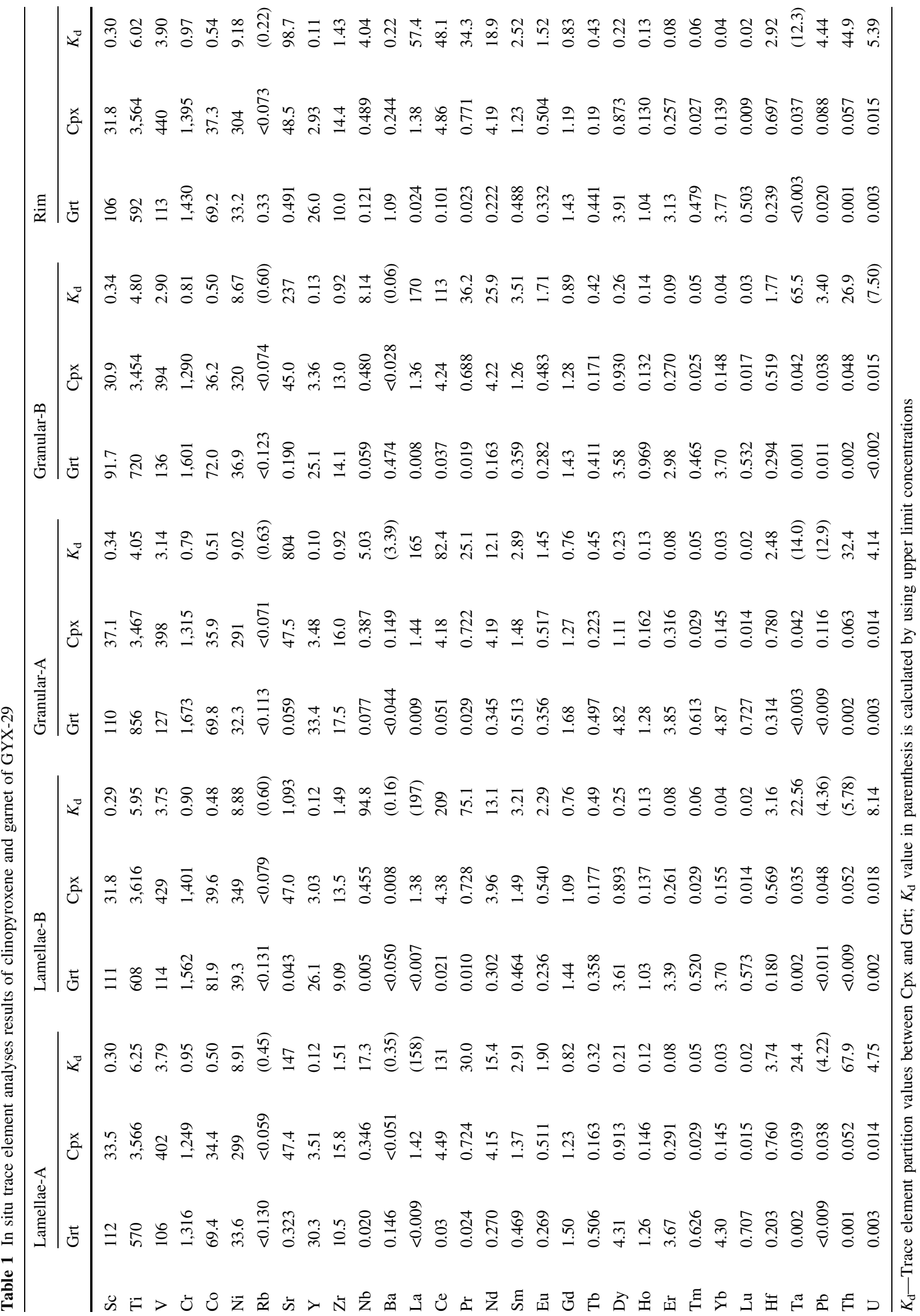


Fig. 9 a Chondrite-normalized REE patterns and $\mathbf{b}$ primitive mantle-normalized spider diagrams of host Cpx, exsolved garnet, and the reconstructed "initial"' Cpx (calculated using $76 \%$ Cpx and $24 \%$ garnet) in GYX-29; $\mathbf{c}$ partitioning of REEs between Grt and Cpx, and $\mathbf{d}$ partitioning of trace elements between Grt and Cpx. Also shown are data of Zack et al. (1997), Harte and Kirkley (1997), and Johnson (1994) for comparison
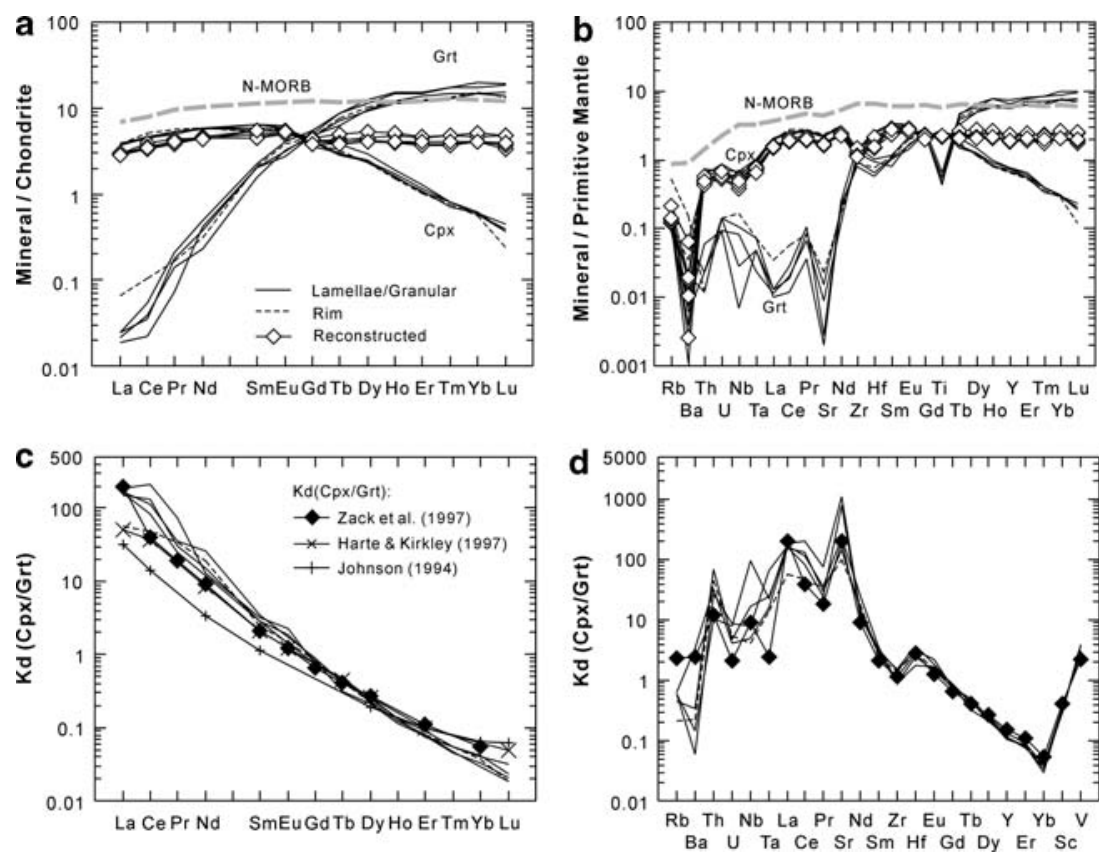

shows an enrichment in HREE and a depletion in LREE, whereas clinopyroxene has flat LREE and HREE-depleted patterns (Fig. 9a). The REE patterns of garnet and clinopyroxene cross at the middle of the REE section (Eu to $\mathrm{Gd})$. In the primitive mantle-normalized spider diagram, clinopyroxene shows depletions of $\mathrm{Rb}, \mathrm{Ba}$ and HREE, whereas garnet is enriched in HREE but depleted in Rb, $\mathrm{Ba}$, Th, U, Nb, Ta, Sr, Ti and LREE (Fig. 9b). Partition coefficients (i.e., $K_{\mathrm{d}}$ values) of trace elements between clinopyroxene and garnet can be calculated using trace element data of coexisting minerals and the results are shown in Fig. 9c, d. The calculated $K_{\mathrm{d}}$ values of REE are comparable with those determined on natural garnet pyroxenites (Zack et al. 1997), in eclogite xenoliths from kimberlite pipe (Harte and Kirkley 1997) and by experimental synthesis (Johnson 1994). The $K_{\mathrm{d}}$ values for other trace elements are also similar to those reported by Zack et al. (1997) (Fig. 9d) except for elements with high RSD in garnets (such as $\mathrm{Rb}$, Th, $\mathrm{U}, \mathrm{Nb}$ and $\mathrm{Ta}$ ) or clinopyroxenes (such as $\mathrm{Rb}, \mathrm{Ba}, \mathrm{Th}, \mathrm{U}, \mathrm{Nb}$ and $\mathrm{Ta}$ ).

\section{Discussion}

Exsolutions in clinopyroxene

Parallel lamellae of garnet and orthopyroxene in clinopyroxene most likely resulted from exsolution from high-Al clinopyroxene megacrysts. The exsolution can be ascribed to the following reactions in the $\mathrm{CaO}-\mathrm{MgO}-\mathrm{Al}_{2} \mathrm{O}_{3}-\mathrm{SiO}_{2}$ (CMAS) system (Sen and Jones 1988; Sautter and Hart 1988):
$\mathrm{CaAlAlSiO}_{6}+2 \mathrm{Mg}_{2} \mathrm{Si}_{2} \mathrm{O}_{6}=\mathrm{Mg}_{3} \mathrm{Al}_{2} \mathrm{Si}_{3} \mathrm{O}_{12}$

$+\mathrm{CaMgSi}_{2} \mathrm{O}_{6}$, (Initial Al - rich Cpx)

$=($ Pyrop Grt $)+($ Cpx host $)$,

$\mathrm{CaAlAlSiO}_{6}+2 \mathrm{CaMgSi}_{2} \mathrm{O}_{6}=\mathrm{Ca}_{3} \mathrm{Al}_{2} \mathrm{Si}_{3} \mathrm{O}_{12}$

$+\mathrm{Mg}_{2} \mathrm{Si}_{2} \mathrm{O}_{6}$, (Initial Al - rich $\mathrm{Cpx}$ )

$=($ Gross Grt $)+(\mathrm{Opx})$.

All fine-strip spinels within host clinopyroxene are parallel (Region L-s in Fig. 2b) and some are parallel to the garnet-orthopyroxene exsolution lamellae (Fig. 4f). This observation strongly suggests that these spinels also represent exsolution products of clinopyroxene. Moreover, the fine-strip spinels in GYX-29 are commonly associated with orthopyroxenes, the latter is cut by the former (Fig. 4h). Because the exsolution of new material must not traverse the earlier lamellae (Clarke and Pe-Piper 1982), such textural relationship suggests that the fine-strip spinels are "older" than the lamellae of orthopyroxene they cross-cut. Accordingly, the exsolution of spinel from clinopyroxene follows the reaction in the CMAS system (Sen and Jones 1988):

$$
\begin{aligned}
& \mathrm{CaAlAlSiO}_{6}+\mathrm{MgAlAlSiO}_{6}+2 \mathrm{Mg}_{2} \mathrm{SiO}_{4}=\mathrm{Mg}_{2} \mathrm{Si}_{2} \mathrm{O}_{6} \\
& +2 \mathrm{MgAl}_{2} \mathrm{O}_{4}+\mathrm{CaMgSi}_{2} \mathrm{O}_{6},(\text { Initial Al }- \text { rich Cpx }) \\
& =(\mathrm{Opx})+(\mathrm{Sp})+(\mathrm{Cpx} \text { host })
\end{aligned}
$$

Spinel and garnet are the main aluminous minerals in the upper mantle. Their occurrence depends on the depth and pressure at which the sample was situated. Similarly, whether the exsolved aluminous phase in Cpx is garnet or 
spinel depends on the stability field in which the Al-rich clinopyroxene recrystallizes as temperature or pressure drops (Green 1966). In general, the garnet stability field has higher pressure than the spinel field. Therefore, the simultaneous exsolution of spinel and garnet from the same Cpx is difficult to justify.

Exsolution of contrasting minerals (spinel versus garnet) in clinopyroxene may be due to the different primary compositions of clinopyroxene (Sen and Jones 1988). This is apparently supported by the slightly low $\mathrm{Al}_{2} \mathrm{O}_{3}$ content in the host clinopyroxene in Region L-s (spinel exsolution, Fig. 2b; Etable 2) compared to that in the Grt exsolution area. The fine-strip spinels might have unmixed from recrystallized clinopyroxene after Grt-Opx exsolution. It is possible that the early exsolution of Grt-Opx lowered the $\mathrm{Al}$ content in $\mathrm{Cpx}$, which was followed by the exsolution of spinel. The fine-strip spinels are all associated with orthopyroxenes, but show no direct contact with garnet lamellae (Region L-s in Figs. 2b, 4h), suggesting that they may be genetically different from Grt-Opx exsolution. Therefore, the contrasting aluminous phases (spinel versus garnet) in GYX-29 are exsolved at different times and probably from different "primary", compositions. Given the different equilibrium condition of spinel and garnet in the mantle, this exsolution order might be accompanied by decrease in pressure. Nevertheless, the co-existence of garnet and spinel in GYX-29 suggests the final $P-T$ conditions very close to the $\mathrm{Sp}-\mathrm{Grt}$ transition zone.

\section{Origin of Sp-Opx-Grt cluster}

The compositional difference between the fine-strip spinels and the coarse spinels (i.e., in the $\mathrm{Sp}-\mathrm{Opx}-\mathrm{Grt}$ cluster) (Fig. 8; Etable 2) suggests that these spinels may not be genetically related. Coarse spinel is commonly enclosed by Opx and garnet (Figs. 2, 4a-d), which is connected to exsolution lamellae. Possibly, it was already present prior to the exsolutions of Opx and garnet. Similar conclusions can be drawn for the bleb-shaped spinels in the lamellar texture zone, which are always included by garnet (Fig. 4e-g). All these suggest that spinel has experienced resorption to varying degrees. The coarse spinels could have crystallized simultaneously with $\mathrm{Cpx}$ megacrysts from a parental magma. In this case, the megacrysts were formed in the stability field of spinel pyroxenites. However, the reconstructed composition of $\mathrm{Cpx}$ before the exsolution of garnet and Opx is suggestive of a pressure higher than that of the spinel stability field (see discussions in next sections). Alternatively, these coarse spinels may represent recrystallized products of exsolution from an "original" Al-rich clinopyroxene (Sen and Jones 1988; Field and Haggerty 1994; Becker 1997). The reason why coarse spinels are mostly distributed at the boundary of differently textured clinopyroxene megacrysts is that the decomposition of "initial" Al-rich clinopyroxene, which led to the formation of spinel, preferentially took place in the rim areas of megacrysts. Similar phenomena have been observed in the upper mantle xenoliths (Field and Haggerty 1994).

These coarse spinels become unstable and are progressively enclosed by exsolved garnet. Thin Opx was developed around the resorbing spinel. This reaction is apparently different from the spinel-garnet transition with which olivine is commonly associated. For example, the subsolidus transition from spinel to garnet, which may be related to temperature decrease or pressure increase could be described as follows (Field and Haggerty 1994; Klemme and O'Neill 2000; Walter et al. 2002):

$$
\begin{aligned}
& \mathrm{MgAl}_{2} \mathrm{O}_{4}+3 \mathrm{CaMgSi}_{2} \mathrm{O}_{6}=\mathrm{Ca}_{3} \mathrm{Al}_{2} \mathrm{Si}_{3} \mathrm{O}_{12} \\
& \quad+\mathrm{Mg}_{2} \mathrm{Si}_{2} \mathrm{O}_{6}+\mathrm{Mg}_{2} \mathrm{SiO}_{4},(\mathrm{Sp})+(\mathrm{Cpx}) \\
& =(\text { Gross Grt })+(\mathrm{Opx})+(\mathrm{Fo})
\end{aligned}
$$

or

$$
\begin{aligned}
& \mathrm{MgAl}_{2} \mathrm{O}_{4}+2 \mathrm{Mg}_{2} \mathrm{Si}_{2} \mathrm{O}_{6}=\mathrm{Mg}_{3} \mathrm{Al}_{2} \mathrm{Si}_{3} \mathrm{O}_{12} \\
& \quad+\mathrm{Mg}_{2} \mathrm{SiO}_{4},(\mathrm{Sp})+(\mathrm{Opx})=(\text { Pyrop Grt })+(\text { Fo })
\end{aligned}
$$

The traverse analyses of Sp-Opx-Grt cluster (Figs. 4d, 5b) reveals no compositional gradients between orthopyroxene, spinel and garnet, suggesting that the transformation interface is grain boundary controlled, where diffusion is typically orders of magnitude faster than volume diffusion (Field and Haggerty 1994). No compositional difference exists between Grt lamellae and those surrounding resorbing spinel in cluster, implying that the reaction may have taken place simultaneously with the exsolution of Grt-Opx lamellae. Therefore, exsolution of spinel from "original", Al-rich clinopyroxene may have occurred before the exsolution of Grt-Opx lamellae.

Reaction aureole surrounding bleb-shaped spinel

The irregular reaction rims of bleb-shaped spinels and coexisting olivines and garnets in GYX-29 (Figs. 3c, d, 4eg) can be ascribed to the reactions of (4) and (5), which involve breakdown of spinel (Field and Haggerty 1994; Klemme and O'Neill 2000; Walter et al. 2002).

The great variations in $\mathrm{SiO}_{2}, \mathrm{Al}_{2} \mathrm{O}_{3}, \mathrm{MgO}$, and $\mathrm{CaO}$ in reaction rims of bleb-shaped spinels suggest that the breakdown of bleb-shaped spinels was taking place while being sampled as a xenolith. In addition, the embayment and vermicular shape of spinel suggest that the spinels of the cluster may have been partially reacted and consumed. Both orthopyroxene and garnet may have been involved in 
the reaction, given the close association with orthopyroxene-garnet (Fig. 4a-d) at the interspace between host clinopyroxene megacrysts (Fig. 2).

Textural development: a petrogenetic link to pyroxenite xenoliths

Based on the wavelength of the exsolution lamellae, Weinbruch et al. (2003) suggested that the exsolution in clinopyroxene could be divided into the early stage of exsolution sensu stricto and the subsequent coarsening process. If the exsolution (sensu stricto) takes place in a manner of spinodal decomposition (Buseck et al. 1980), the average wavelength of the lamellae remains constant. Coarsening is diffusion controlled and is time- and temperature-dependent (Weinbruch et al. 2003). The fact that the wavelength of the lamellae in GYX-29 is not constant points to the involvement of coarsening processes, which develop with annealing time (McCallister 1978; Weinbruch et al. 2003). In particular, recrystallization of the lamellar zone of megacrysts gave rise to the formation of the granular texture. In the granular zone, $\mathrm{Cpx}$ is the largest in grain size, and garnet is generally of elongated shape and runs parallel to the exsolved lamellae in the host megacrysts (Fig. 2). This suggests that the granular zone is an integrated part of the Cpx megacryst and may have been developed from lamellar texture by partial textural reequilibration, probably as a result of reduction of surface free energy along the lamellae (Clarke and Pe-Piper 1982). Hence, GYX-29 has attained the present textural state by a process of multiple exsolution and subsequent recrystallization. The textural development in GYX-29 likely starts with lamellar garnet-orthopyroxene, through orientated bleb-shaped garnet-orthopyroxene, and finally evolves to crack-filled and intergranular garnet-orthopyroxene. This feature is important, as it implies a possible genetic relationship between exsolved clinopyroxene megacrysts and normal granular pyroxenite xenoliths (Clarke and Pe-Piper 1982; Griffin et al. 1984). The exsolved Opx, Cpx, Grt, and Sp in GYX-29 compositionally resemble the respective minerals in the pyroxenite xenoliths from South China (Xu et al. 1996, 2002; Yu et al. 2003) (Figs. 6-8a). Therefore, at least some pyroxenite xenoliths may have originated from Cpx megacryst through exsolution and subsequent recrystallization.

\section{P-T estimation}

Garnet exsolution is common in eclogite xenolith from kimberlites, such as Roberts Victor of South Africa (Sautter and Hart 1988, 1990) and Yakutia in Russia (Jerde et al. 1993). Significant compositional gradient between exsolution lamellae is interpreted as a result of a rapid cooling rate in the mantle and a short residence time following garnet exsolution (Sautter and Hart 1988, 1990; Jerde et al. 1993). In contrast, no compositional diffusion gradient has been observed in the host Cpx adjacent to Grt and Opx in the case of GYX-29. This suggests a relatively slow cooling rate in the mantle and a relatively long residence time after the Grt-Opx exsolution. The extensive garnet exsolution from clinopyroxene indicates a large temperature decrease or a possible pressure increase (e.g., Harte and Gurney 1975; Zhang and Liou 2003).

\section{Reconstructed composition of original clinopyroxene and pre-exsolution P-T condition}

The initial compositions of clinopyroxene prior to exsolution can be reconstructed in three ways: (1) chemical analysis of the powder of whole megacrysts including host clinopyroxene and exsolution lamellae (Zhang and Liou 2003); (2) calculation using the individual mineral analyses and the modal abundances obtained by point counting in thin sections (Clarke and Pe-Piper 1982); and (3) point reintegration by using electron microprobe with a large probe beam (Liu et al. 2003). The third method is not suitable for GYX-29 because of the large thickness of exsolution lamellae in this sample. GYX-29 is made of several megacryst aggregates, making it difficult to separate the single megacryst for chemical analyses. EMP analyses demonstrate that chemical equilibrium had been reached among the host clinopyroxene and exsolved garnet-orthopyroxene. Trace element data provide additional evidence for the chemical equilibrium between the hosts and exsolved materials in GYX-29 (Fig. 9c, d). It is therefore appropriate to adopt the second method to reconstruct the composition of "initial" unexsolved clinopyroxene. The proportions of host clinopyroxene and exsolved garnet and orthopyroxene are estimated in three parts of two thin sections. The results (Etable 3) are similar: clinopyroxene $72.2-74.8 \%$, orthopyroxene $3.3-5.5 \%$ and garnet $19.6-23.5 \%$. The fine-strip spinel and the blebshaped spinel are not taken into account in these calculations because of their very low-mode percentage. The reconstructed bulk composition of the "initial" clinopyroxene shows distinctively high $\mathrm{Al}_{2} \mathrm{O}_{3}$ content (ca. 10.5 wt.\%, Etable 3), and has end-members of $\mathrm{En}_{50}$ $\mathrm{Fs}_{11} \mathrm{Wo}_{39}$ and $\mathrm{Jd}$ content of $\sim 5.7 \%$. A higher $\mathrm{Al}_{2} \mathrm{O}_{3}$ estimate can be obtained if the spinels in cluster are considered to be early exsolution products as well. Consequently, the results in Etable 3 may represent minimum estimates of the original composition of unexsolved $\mathrm{Cpx}$.

Because of its small mode and low concentration of incompatible elements, orthopyroxene is not considered in the reconstruction of trace element composition. The calculation with $76 \% \mathrm{Cpx}$ and $24 \%$ Grt shows a nearly flat 
Table 2 P-T results of exsolved clinopyroxene megacrysts and reconstructed clinopyroxene

\begin{tabular}{|c|c|c|c|c|c|c|c|c|c|c|c|}
\hline \multirow[t]{2}{*}{ Regions } & \multicolumn{3}{|c|}{ Reconstruction Cpx } & \multicolumn{8}{|c|}{ Re-equilibration after the exsolution } \\
\hline & $\begin{array}{l}\mathrm{T} 1 \\
\mathrm{Cpx}\end{array}$ & $\begin{array}{l}\text { T2 } \\
\text { Cpx(Grt) }\end{array}$ & $\begin{array}{l}\mathrm{P} 1 \\
\mathrm{Cpx}\end{array}$ & $\begin{array}{l}\text { T3 } \\
\text { Opx-Cpx }\end{array}$ & $\begin{array}{l}\text { T4 } \\
\text { Opx-Cpx }\end{array}$ & $\begin{array}{l}\text { T5 } \\
\text { Grt-Cpx }\end{array}$ & $\begin{array}{l}\text { T6 } \\
\text { Grt-Cpx }\end{array}$ & $\begin{array}{l}\text { P2 } \\
\text { Grt-Opx }\end{array}$ & $\begin{array}{l}\text { P3 } \\
\text { Grt-Opx }\end{array}$ & $\begin{array}{l}\text { P4 } \\
\text { Opx(Grt) }\end{array}$ & $\begin{array}{l}\text { P5 } \\
\text { Opx }\end{array}$ \\
\hline Granular part-a & 1,220 & 1,227 & 16.4 & 878 & 925 & 864 & 886 & 12.3 & 11.6 & 12.4 & 12.2 \\
\hline Lamellae part-a & 1,202 & 1,201 & 15.9 & 888 & 920 & 877 & 910 & 12.7 & 12.1 & 12.8 & 12.0 \\
\hline Lamellae part-b & 1,208 & 1,209 & 16.2 & 881 & 928 & 890 & 917 & 12.4 & 11.6 & 12.5 & 12.2 \\
\hline
\end{tabular}

T1 Nimis and Taylor (2000); T2 Mercier (1980); P1 Nimis (1999); T3 Bertrand and Mercier (1986); T4 Wells (1977); T5 Ellis and Green (1979); T6 Krogh (1988); P2 Nickel and Green (1985); P3 Wood (1988); P4 Mercier (1980); P5 Brey and Köhler (1990)

REE pattern with weak depletion in LREE (Fig. 9a) and strong depletion in $\mathrm{Rb}, \mathrm{Ba}, \mathrm{Th}, \mathrm{U}, \mathrm{Nb}$ and $\mathrm{Ta}$ (Fig. 9b). This pattern resembles that of the $N$-type MORB (Sun and McDonough 1989), though at a concentration level (Fig. 9b).

The P-T conditions can be inferred from the reconstructed compositions of original clinopyroxene by using single-pyroxene geothermometry (Mercier 1980; Nimis and Taylor 2000) and geobarometry (Nimis 1999). Nimis and Taylor (2000) thermometer yields virtually the same temperatures for reconstructed compositions of pre-exsolution $\mathrm{Cpx}$ in three different regions $\left(1,202-1,220^{\circ} \mathrm{C}\right.$, Table 2) with an average of $1,210^{\circ} \mathrm{C}$. Similar temperature estimates $\left(1,201-1,227^{\circ} \mathrm{C}\right.$, Table 2$)$ are obtained by Mercier (1980) geothermometry. The uncertainty associated with thermometric calculation involves intrinsic error of thermometer calibration and that of reconstructed composition propagated from mode estimation. The error associated with the calibration of the thermometer is $\pm 30^{\circ} \mathrm{C}$ (Nimis and Taylor 2000). The error propagating from the uncertainty associated with mode estimate $(5 \%)$ is $\pm 25^{\circ} \mathrm{C}$. It is important to note that temperature estimates obtained from three different reconstructed compositions (i.e., different mode estimates) are rather similar, with a standard deviation of only $9{ }^{\circ} \mathrm{C}$. This suggests that error linked to mode estimate may be fairly small. Given the fact that the thermometer error already partly takes into account compositional uncertainty of experimental calibration, it can be reasonable to infer that the error of temperature estimation of GYX-29 is no more than $30^{\circ} \mathrm{C}$.

The clinopyroxene megacryst aggregate may be derived from a MORB-type high-degree melt based on the trace element pattern (Fig. 9b); thus, the single-pyroxene geobarometer for tholeiitic system of Nimis (1999) is adapted to calculate the pressure of unexsolved clinopyroxene. An estimate of pressure of $\sim 16.2 \mathrm{kbar}$ (Table 2) is obtained by this structural geobarometer. An error of $30^{\circ} \mathrm{C}$ in temperature estimation will translate to an uncertainty of $\sim 1.3 \mathrm{kbar}$ in calculated pressure. The compositional uncertainty conveyed from $5 \%$ error in mode estimation will also yield an uncertainty of $\sim 0.4$ kbar. These uncertainties are all within the geobarometer error of $\pm 1.8 \mathrm{kbar}$ (Nimis 1999). It is unclear how all these errors are accumulated. A conservative estimate is \pm 3.5 kbar. To sum up, unexsolved clinopyroxene of GYX-29 was likely equilibrated at $1,210 \pm 30^{\circ} \mathrm{C}$ and $16.2 \pm 3.5$ kbar.

\section{Equilibrium P-T after the exsolution}

A number of geothermometers and geobarometers are available for the P-T estimation for the Grt-Cpx-Opx assemblage, including two pyroxene thermometers (Wells 1977; Bertrand and Mercier 1986), Grt-Cpx thermometers (Ellis and Green 1979; Krogh 1988), Grt-Opx geobarometers (Nickel and Green 1985; Wood 1974) and the Al-inOpx barometer of Brey and Köhler (1990). All these thermometers yield similar estimates of $900 \pm 30^{\circ} \mathrm{C}(\mathrm{Ta}-$ ble 2). Application of Grt-Opx geobarometers (Nickel and Green 1985; Wood 1974), single-pyroxene geobarometer of Mercier (1980) and the Al-in-Opx barometer of Brey and Köhler (1990) give pressure values of 11.6-12.8 kbar (Table 2). Although the estimate range is quite narrow, the implicated pressure is likely to be $12 \pm 2.2 \mathrm{kbar}$, considering $2.2 \mathrm{kbar}$ uncertainties associated with the Al-in-Opx barometer of Brey and Köhler (1990). A combination of the Brey and Köhler (1990) Al-in-Opx barometer and the Krogh (1988) Grt-Cpx thermometer is capable of reproducing experimental conditions (Brey and Köhler 1990). Therefore, the exsolved garnet-orthopyroxene and host clinopyroxene were finally re-equilibrated at $900 \pm 30^{\circ} \mathrm{C}$ and $12 \pm 2.2$ kbar. These estimates are consistent with the present-day thermal gradient in the Leizhou Peninsula (Fig. 10; Yu et al. 2003; Lin et al. 2003), again attesting the full equilibration of this sample with the ambient mantle.

Although the pressure estimate of pre-exsolution $(16.2 \pm 3.5 \mathrm{kbar})$ and the post-exsolution $(12 \pm 2.2 \mathrm{kbar})$ overlap within error, petrologic evaluation suggests preexsolution megacryst was equilibrated within the garnet pyroxenite stability field, while exsolution of spinel suggests a stage within the spinel pyroxenite stability field. 


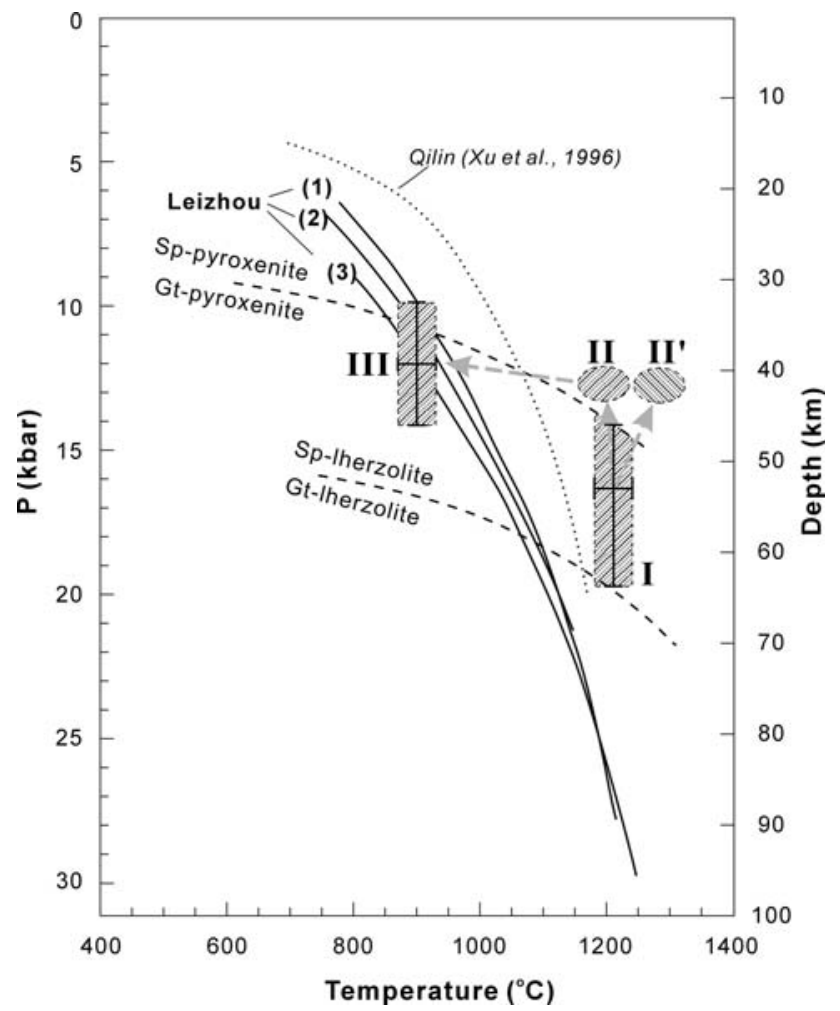

Fig. 10 Schematic diagram illustrating the thermal evolution of GYX-29. Leizhou geotherms (1) and (3) from Yu et al. (2003) constructed using different thermometer-barometer combinations, Leizhou geotherm (2) from Lin et al. (2003), Qilin geotherm from Xu et al. (1996). The spinel pyroxenite-garnet pyroxenite boundary is from Herzberg (1978)

\section{Thermal evolution of the sample GYX-29}

Considerable difference is noted between the pre-exsolution condition $\left(1,210 \pm 30^{\circ} \mathrm{C}\right.$ and $\left.16.2 \pm 3.5 \mathrm{kbar}\right)$ and the post-exsolution equilibrium condition $\left(900 \pm 30^{\circ} \mathrm{C}\right.$ and $12 \pm 2.2$ kbar). Similar results have been found in xenoliths and megacrysts from many other locations; for example, Clarke and Pe-Piper (1982) showed that clinopyroxene megacrysts from the Frank Smith mine of South Africa, which was initially equilibrated at $\sim 1,500^{\circ} \mathrm{C}$ and $37 \mathrm{kbar}$, re-equilibrated at $900^{\circ} \mathrm{C}$ and $35 \mathrm{kbar}$ after exsolution. Cooling from near-solidus conditions toward normal mantle lithosphere temperature has also been invoked to explain the exsolution in ecologite xenolith from Roberts Victor kimberlite pipe, South Africa (Harte and Gurney 1975; Sautter and Hart 1988, 1990). Tremendous changes in temperature and pressure were also invoked to explain the garnet exsolution in clinopyroxene from the Sulu ultrahigh-pressure terrane, eastern China (Zhang and Liou 2003). All these observations suggest that change in P-T condition may be the driving force of exsolution in Cpx megacrysts (Aoki et al. 1980; Clarke and Pe-Piper 1982;
Sen and Jones 1988; Sautter and Hart 1988; Zhang and Liou 2003; Xu et al. 2004).

The $P-T$ of reconstructed "initial" clinopyroxene makes GYX-29 to be situated to the right of the Qilin geotherm and the present-day Leizhou geotherm (position I, Fig. 10). Although a single sample does not allow to define a geotherm, the high temperature $\left(>1,200^{\circ} \mathrm{C}\right)$ at the modest pressure $(\sim 16 \mathrm{kbar})$ is probably indicative of a very high thermal gradient. The post-exsolution $P-T$ of GYX-29 is plotted along the Leizhou geotherm (position III of Fig. 10), indicating the full re-equilibrium of this sample with the ambient lithosphere. The contrast in thermal state before and after the exsolution in clinopyroxene megacrysts of GYX-29 mirrors the thermal evolution of the lithosphere beneath South China during the Cenozoic. Specifically, the evolution of GYX-29 may be composed of the following stages:

(a) The clinopyroxene megacryst aggregate was initially stable at $1,210 \pm 30^{\circ} \mathrm{C}$ and $16.2 \pm 3.5 \mathrm{kbar}$ in the garnet-pyroxenite stability field (i.e., position I, Fig. 10). They may have crystallized from a MORBtype magma derived from the asthenosphere by large degree melting at high temperature.

(b) This high-Al clinopyroxene megacryst aggregate was then partially re-equilibrated within the spinelpyroxenite stability field (position II or II', Fig. 10). Some orthopyroxenes and high $\mathrm{Cr} / \mathrm{Al}$ coarse spinels may have been formed at this stage by exsolution from "initial" high-Al clinopyroxene megacrysts. If the megacryst aggregate was part of the asthenosphere, then the transition from I to II involves nearly isothermal decompression. If it was part of the lithosphere, then decompression must have been accompanied by heating (from position I to $\mathrm{II}^{\prime}$, Fig. 10) because of the hotter asthenosphere. In any case, the transition was probably accompanied by the upwelling asthenosphere, which protruded into the stretched and decompressed lithosphere $\mathrm{Xu}$ et al. 2002; Yu et al. 2003).

(c) Exsolution of Grt-Opx in clinopyroxene occurred as a consequence of temperature decrease during the transition from the spinel-pyroxenite field to the garnet-pyroxenite field (from position II or II' to III, Fig. 10). Specifically, the garnet-orthopyroxene resulted from exsolution of the high-Al clinopyroxene megacrysts. The $\mathrm{Sp}-\mathrm{Opx}-\mathrm{Grt}$ cluster was formed at the expense of spinel (Fig. 4a-d). This transition likely took place during the thermal decay of the lithosphere as a result of downwelling of the asthenosphere (Yu et al. 2003; Lin et al. 2003). This is compatible with surface heat flow modeling in the northern margin of South China Sea (He et al. 2001), 
where the basement heat flow increased during crustal extension and decreased when extension stopped since Miocene.

(d) The exsolved orthopyroxene-garnet and host clinopyroxene reached chemical equilibrium through diffusion and thermally re-equilibrated with ambient mantle. This is indicated by the fact that the postexsolution $P-T$ conditions correspond to the current Leizhou thermal gradient (position III of Fig. 10). The granular texture was probably developed during this thermal equilibration from lamellae part along the margins of clinopyroxene megacrysts. Some fine-strip spinels coexisting with orthopyroxenes could have exsolved from re-equilibrated host clinopyroxene as the $P-T$ condition approached that of the $\mathrm{Sp}-\mathrm{Grt}$ transition zone.

Acknowledgments We gratefully acknowledge the constructive comments of L. Taylor, S. Tappe, and an anonymous reviewer, which helped improve the manuscript. Dr. Y.S. Liu is thanked for his kind help during the LA-ICP-MS analyses and Dr. X.C. Liu for helpful discussions on the initial draft. The financial supports from the China National Science Foundation (40421303, 40202009, 40673038, and 49925308) and the Chinese Academy of Sciences (KZCX2-101, KZCX2-209, the Bairen Project) are gratefully acknowledged. This represents part of a collaborative research program of the Guangzhou Institute of Geochemistry, Chinese Academy of Sciences and the Department of Geosciences, National Taiwan University.

\section{References}

Aoki K, Fujimaki H, Kitamura M (1980) Exsolved garnet-bearing pyroxene megacrysts from some south African kimberlites. Lithos 13:269-279

Becker H (1997) Petrological constraints on the cooling history of high-temperature garnet peridotite massifs in lower Austria. Contrib Mineral Petrol 128:272-286

Bertrand P, Mercier J-CC (1985) The mutual solubility of coexisting ortho- and clinopyroxene: toward an absolute geothermometer for natural system? Earth Planet Sci Lett 76:109-122

Brey GP, Köhler T (1990) Geothermobarometry in four-phase lherzolites: II. New thermobarometers, and practical assessment of existing thermobarometers. J Petrol 31:1353-1378

Buseck PR, Nord GL, Veblen DR (1980) Subsolidus phenomena in pyroxenes. In: Prewitt CT (ed) Reviews in mineralogy, pyroxenesm. vol 7. Mineralogical Society of America, Washington, pp $117-211$

Clarke DB, Pe-Piper GG (1982) Multiply exsolved clinopyroxene megacrysts from the Frank Smith mine, Cape province, South Africa. Lithos 16:75-84

Desnoyers C (1975) Exsolutions d'amphibole, de grenat et de spinelle dans les pyroxenes de roches ultrabasiques: periodtites et pyroxenolites. Bull Soc Fr Min Cristal 98:65-77

Ellis DJ, Green DH (1979) An experimental study of the effect of Ca upon garnet-clinopyroxene $\mathrm{Fe}-\mathrm{Mg}$ exchange equilibria. Contrib Mineral Petrol 71:13-22

Fan WM, Menzies MA (1992) The composition of lithospheric mantle in rifting volcanism environment: geochemical evidence from Cenozoic basaltic rocks from Leiqiong area. In: Liu RX (ed) Geochronology and geochemistry of Cenozoic volcanic rocks in China. Seismic Press, Beijing, pp 320-329 (in Chinese)

Field SW, Haggerty SE (1994) Symplectites in upper mantle peridotites: development and implications for the growth of subsolidus garnet, pyroxene and spinel. Contrib Mineral Petrol 118:138-156

Green DH (1966) The origin of "eclogites" from Salt Lake crater, Hawaii. Earth Planet Sci Lett 1:414-420

Griffin WL, Wass SY, Hollis JD (1984) Ultramaffic xenoliths from Bullenmerri and Gnotuk maars, Victoria, Australia: petrology of a sub-continental crust-mantle transition. J Petrol 25:53-87

Harte B, Gurney JJG (1975) Evolution of clinopyroxene and garnet in an eclogite nodule from the Roberts Victor kimberlite pipe, South Africa. Phys Chem Earth 9:367-387

Harte B, Kirkley MB (1997) Partitioning of trace elements between clinopyroxene and garnet: data from mantle eclogites. Chem Geol 136:1-24

He LJ, Wang KL, Xion LP, Wang JY (2001) Heat flow and thermal history of the South China Sea. Phys Earth Planet Inter 126:211220

Herzberg C (1978) Pyroxene geothermometry and geobarometry: experimental and thermodynamic evaluation of some subsolidus phases relations involving clinopyroxenes in the system $\mathrm{CaO}$ $\mathrm{MgO}-\mathrm{Al}_{2} \mathrm{O}_{3}-\mathrm{SiO}_{2}$. Geochim Cosmochim Acta 42:945-957

Ho KS, Chen JC, Juang WS (2000) Geochronology and geochemistry of late Cenozoic basalts from the Leiqiong area, souther China. J Asian Earth Sci 18:307-324

Jerde EA, Taylor LA, Crozaz G, Sobolev NV (1993) Exsolution of garnet within clinopyroxene of mantle eclogites: major and trace-element chemistry. Contrib Mineral Petrol 114:148-159

Johnson KTM (1994) Experimental cpx/and garnet/melt partitioning of REE and other trace elements at high pressures: petrogenetic implications. Mineral Mag 58A:454-455

Klemme S, O'Neill HStC (2000) The near-solidus transition from garnet lherzolite to spinel lherzolite. Contrib Mineral Petrol 138:237-248

Krogh EJ (1988) The garnet-clinopyroxene Fe-Mg geothermometer-a reinterpretation of existing experimental data. Contrib Mineral Petrol 99:44-48

Lappin MA, Dawson BD (1975) Two Roberts-Victor cumulate eclogites and their re-equilibration. Phys Chem Earth 9:351-365

Lin CY, Huang XL, Xu YG, Shi LB, Chen XD (2003) Thermal structure and rheology of upper mantle beneath Leizhou Peninsula, Guangdong Province, China. J Trop Oceanogr 22:49-62 (in Chinese with English abstract)

Liu XC, Zhao ZR, Zha Y, Chen J, Liu XH (2003) Pyroxene exsolution in mafic granulites from the Grove Mountains, east Antarctiva: constraints on Pan-African metamorphic conditions. Eur J Mineral 15:55-65

McCallister RH (1978) The coarsening kinetics associated with exsolution in an iron-free clinopyroxene. Contrib Mineral Petrol 65:327-331

Mercier J-CC (1980) Single-pyroxene thermobarometry. Tectonophysics 70:1-37

Mercier J-CC, Nicolas A (1975) Textures and fabrics of upper-mantle peridotites as illustrated by xenoliths from basalts. J Petrol $16: 454-487$

Nickel HG, Green DH (1985) Empirical geothermobarometry for garnet peridotites and implications for the nature of the lithosphere, kimberlites and diamonds. Earth Planet Sci Lett 73:158-170

Nimis P, Taylor WR (2000) Single clinopyroxene thermobarometry for garnet peridotites. Part I: calibration and testing of a Cr-inCpx barometer and an enstatite-in-Cpx thermometer. Contrib Mineral Petrol 139:541-554 
Nimis P (1999) Clinopyroxene geobarometry of magmatic rocks. Part 2. Structural geobarometers for basic to acid, tholeiitic and mildly alkaline magmatic systems. Contrib Mineral Petrol 135:62-74

Qi Q, Taylor LA, Zhou XM (1995) Petrology and geochemistry of mantle peridotite xenoliths from SE China. J Petrol 36:55-79

Reiche M, Bautsch H-J (1985) Electron microscopical study of garnet exsolution in orthopyroxene. Phys Chem Mineral 12:29-33

Sautter V, Hart B (1988) Diffusion gradients in an eclogite xenolith from the Roberts Victor kimberlite pipe: 1. Mechanism and evolution of garnet exsolution in $\mathrm{Al}_{2} \mathrm{O}_{3}$-rich clinopyroxene. $\mathrm{J}$ Petrol 29:1325-1352

Sautter V, Hart B (1990) Diffusion gradients in an eclogite xenolith from the Roberts Victor kimberlite pipe: (2) kinetics and implications for petrogenesis. Contrib Mineral Petrol 105:637649

Schmickler B, Jacob DE, Foley SF (2004) Eclogite xenoliths from the Kuruman kimberlites, South Africa: geochemical fingerprinting of deep subduction and cumulate processes. Lithos 75:173-207

Sen G, Jones RE (1988) Exsolved silicate and oxide phases from clinopyroxenes in a single Hawaiian xenolith: implications for oxidation state of the Hawaiian upper mantle. Geology 16:6972

Sun S-s, McDonough WF (1989) Chemical and isotopic systematics of oceanic basalts: implications for mantle composition and processes. In: Saunders AD, Norry MJ (eds) Magmatism in the Ocean Basins. Geological Society, London, pp 313-345

Walter M, Katsura T, Kubo A, Shinmei T, Nishikawa O, Ito E, Lesher C, Funakoshi K (2002) Spinel-garnet lherzolite transition in system $\mathrm{CaO}-\mathrm{MgO}-\mathrm{Al}_{2} \mathrm{O}_{3}-\mathrm{SiO}_{2}$ revisited: an in situ X-ray study. Geochim Cosmochim Acta 66:2109-2121
Weinbruch S, Styrsa V, Müller WF (2003) Exsolution and coarsening in iron-free clinopyroxene during isothermal annealing. Geochim Cosmochim Acta 67:5071-5082

Wells PRA (1977) Pyroxene thermometry in simple and complex systems. Contrib Mineral Petrol 62:129-139

Wood BJ (1974) Solubility of alumina in orthopyroxene coexisting with garnet. Contrib Mineral Petrol 46:1-15

$\mathrm{Xu}$ WL, Liu XC, Wang QH, Lin JQ, Wang DY (2004) Garnet exsolution in garnet clinopyroxenite and clinopyroxenite xenoliths in early Cretaceous intrusions from the Xuzhou region, eastern China. Mineral Mag 68:443-453

Xu XS, O'Reilly SY, Zhou XM, Griffin WL (1996) A xenolithderived geotherm and the crust-mantle boundary at Qilin, southeastern China. Lithos 38:41-62

Xu YF, Zhu ZH, Wen Q, Wen G, Pu ZH (1999) Clay mineral, chemical characteristics and environmental record of the multistage laterite at Yingfengling section, Leizhou Peninsula. Geochimica 28:281-288 (in Chinese with English abstract)

Xu YG, Sun M, Yan W, Liu Y, Huang XL, Chen XM (2002) Xenolith evidence for polybaric melting and stratification of the upper mantle beneath South China. J Asian Earth Sci 20:937-954

Yu JH, O'Reilly SY, Griffin WL, Xu X, Zhang M, Zhou X (2003) The thermal state and composition of the lithospheric mantle beneath the Leizhou Penisula South China. J Volcanol Geotherm Res 122:165-189

Zack T, Foley SF, Jenner GA (1997) A consistent partition coefficient set for clinopyroxene, amphibole and garnet from laser ablation microprobe analysis of garnet pyroxenites from Kakanui, New Zealand. Neues Jahrb Mineral Abhirchen 172:23-41

Zhang RY, Liou JG (2003) Clinopyroxenite from the Sulu ultrahighpressure terrane, eastern China: origin and evolution of garnet exsolution in clinopyroxene. Am Mineral 88:1591-1600 